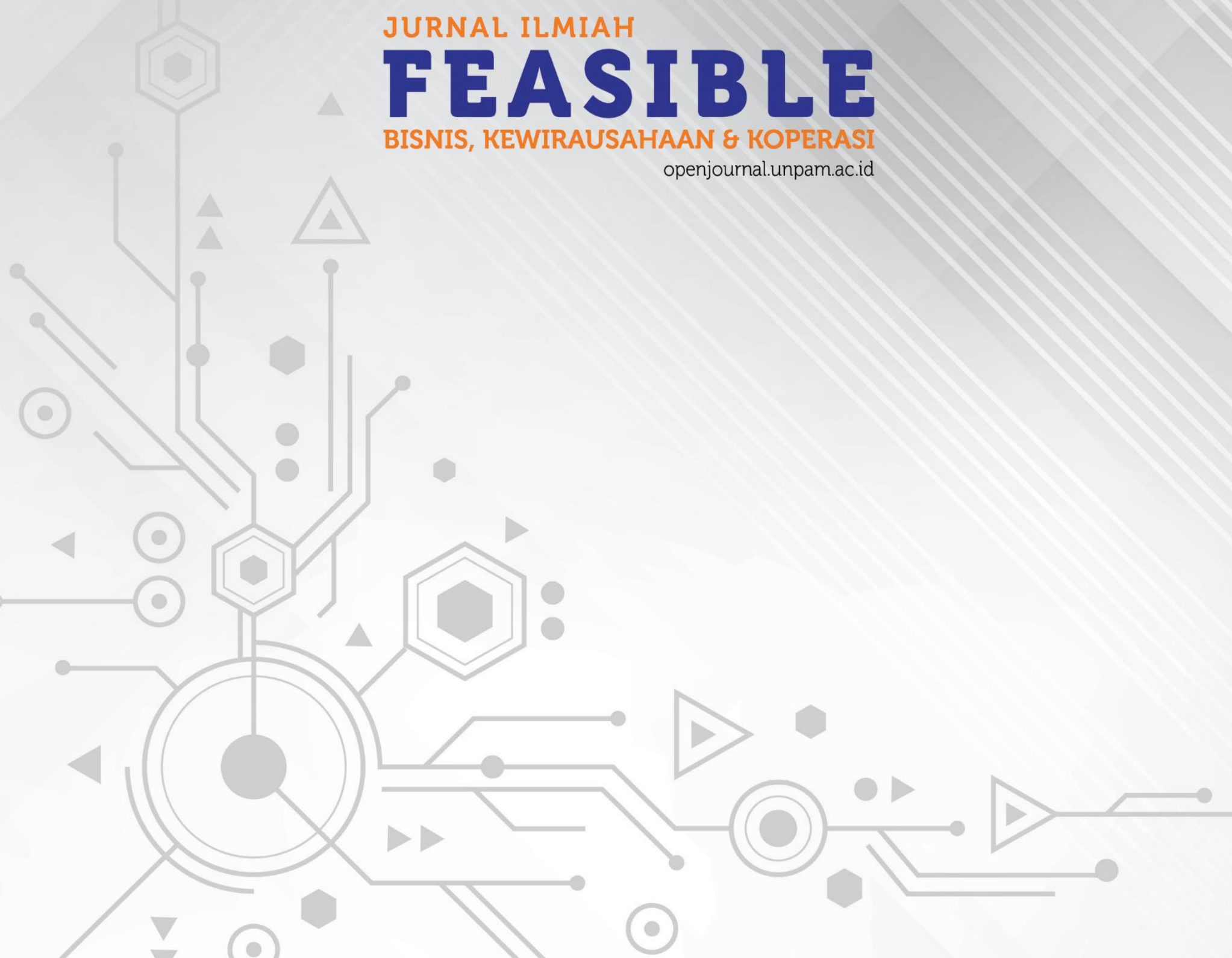




\title{
PENGARUH KUALITAS PRODUK TERHADAP KEPUASAN KONSUMEN PADA PT. KOBE BOGA UTAMA TANGERANG
}

\author{
Mutmainnah \\ Fakultas Ekonomi Universitas Pamulang \\ doseno1720@unpam.ac.id
}

\begin{abstract}
Abstrak
Tujuan dari penelitian ini adalah untuk mengetahui kualitas produk pada PT. Kobe Boga Utama, mengetahui bagaimana kepuasan pelanggan pada PT. Kobe Boga Utama, dan mengetahui pengaruh kualitas produk terhadap kepuasan pelanggan pada PT. Kobe Boga Utama. Metode penelitian yang digunakan adalah kuantitatif deskriptif. Adapun teknik sampel yang digunakan adalah teknik sampel Accidental Sampling yang berjumlah 97 responden. Metode analisis yang digunakan adalah regresi linear terdiri dari uji validitas, uji reliabilitas, uji koefisien korelasi, uji koefisien determinasi, uji regresi sederhana, dan uji hipotesis. Hasil analisis deskripsi menunjukkan kualitas produk PT. Kobe Boga Utama dipersepsikan baik, hal ini dapat dilihat pada nilai rata-rata jawaban responden sebesar 4,06. Kepuasan konsumen PT. Kobe Boga Utama dipersepsikan baik, hal ini dapat dilihat pada nilai rata-rata jawaban responden sebesar 4,05. Adapun hasil analisis regresi menunjukkan kualitas produk berpengaruh positif dan signifikan terhadap kepuasan konsumen dengan hasil $t_{\text {hitung }}>t_{\text {tabel }}$ sebesar $(2.034>1.985)$ dan persamaan $Y=31.808+$ o.224X, artinya $H_{o}$ ditolak dan $H a$ diterima. Dengan tafsiran, jika kualitas produk meningkat sebesar 1 satuan maka kepuasan konsumen akan meningkat sebesar o.224.
\end{abstract}

Kata Kunci : Kualitas Produk, Kepuasan Konsumen

\begin{abstract}
The purpose of this study was to determine the quality of products at PT. Kobe Boga Utama, knows how customer satisfaction at PT. Kobe Boga Utama, and know the effect of product quality on customer satisfaction at PT. Kobe Boga Utama. The research method used is quantitative descriptive. The sample technique used is the Accidental Sampling technique, which amounted to 97 respondents. The analytical method used is linear regression consisting of validity test, reliability test, correlation coefficient test, test coefficient of determination, simple regression test, and hypothesis testing. The results of the description analysis show the product quality of PT. Kobe Boga Utama is perceived well, this can be seen in the average value of respondents' answers of 4.06. Customer satisfaction PT. Kobe Boga Utama is perceived well, this can be seen in the average value of respondents' answers of 4.05. The results of regression analysis indicate that product quality has a positive and significant effect on consumer satisfaction with the results of tcount $>$ ttable of (2.034>1.985) and the equation $Y=31.808+0.224 X$, meaning Ho is rejected and Ha is accepted. With interpretation, if product quality increases by 1 unit, customer satisfaction will increase by 0.224 .
\end{abstract}

Keywords : Product Quality, Customer Satisfaction 


\section{PENDAHULUAN}

\section{Latar Belakang}

PT. Kobe Boga Utama dengan produk unggulannya Tepung Bumbu Kobe merupakan salah satu merek tepung bumbu yang saat ini banyak digemari oleh pelanggan karena kepraktisannya, rasanya yang enak dan harga yang terjangkau, akan tetapi pada kenyataannya kondisi kepuasan pelanggan saat ini jauh dari yang diharapkan. Banyak pelanggan yang merasa kecewa dengan produk tepung bumbu ini, ada pelanggan yang mendapatkan tepung bumbu yang sudah kadaluarsa sehingga tidak layak makan, serta harga yang ditawarkan saat ini mengalami peningkatan yang tentu sangat memberi dampak yang kurang baik bagi kalangan pelanggan menengah ke bawah. Berikut data penjualan PT. Kobe Boga Utama.

Tabel 1.1. Penjualan PT. Kobe Boga Utama Tahun
\begin{tabular}{|c|c|c|c|}
\hline \multicolumn{5}{|c|}{ 2013 - 2017 } \\
\hline Tahun & Penjualan (Rp) & Persentase & Keterangan \\
\hline 2013 & $831.907 .006,33$ & - & - \\
\hline 2014 & $688.102 .441,20$ & $-17.29 \%$ & turun \\
\hline 2015 & $593.070 .612,09$ & $-13.81 \%$ & turun \\
\hline 2016 & $665.014 .278,14$ & $12.13 \%$ & naik \\
\hline 2017 & $601.432 .094,19$ & $-9.56 \%$ & turun \\
\hline
\end{tabular}
Sumber : Laporan Keuangan PT. Kobe Boga Utama (2018) Data di atas secara sederhana dapat dilihat dalam model diagram, berikut:

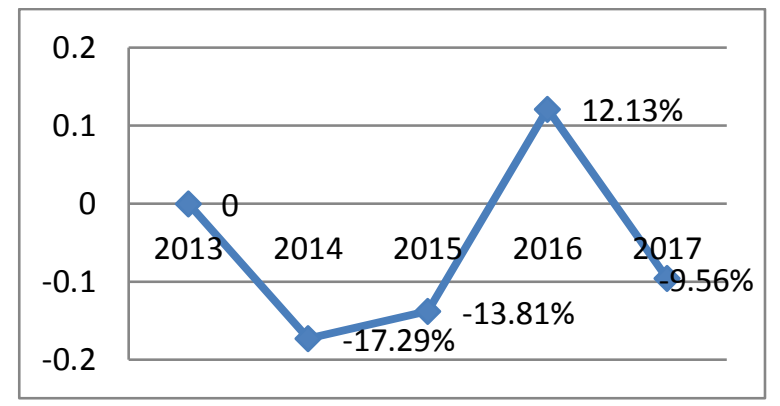

Gambar 1.1. Diagram Penjualan PT. Kobe Boga Utama
Data di atas menunjukkan bahwa penjualan PT. Kobe Boga Utama mengalami tren penurunan, bahkan jika dilihat dari persentase pertumbuhan menunjukkan posisi penjualan yang stagnasi. Kondisi ini mengisyaratkan bahwa prilaku pelanggan di era digital sulit diprediksi dan butuh upaya keras untuk dapat meningkatkan daya beli masyarakat, salah satunya dengan menghadirkan produk bermutu (berkualitas). Sejalan dengan penjelasan di atas, PT Kobe Boga Utama menyadari bahwa kepuasan pelanggan adalah hal yang paling penting dalam mata rantai pemasaran, oleh karenanya menghadirkan produk yang berkualitas merupakan tantangan tersendiri bagi PT Kobe Boga Utama dalam rangka menciptakan kepuasan pelanggan. Namun dalam prakteknya, PT Kobe Boga Utama menyadari banyaknya populasi atau masyarakat Indonesia tentu memiliki karakteristik yang sangat beragam, sehingga upaya PT Kobe Boga Utama memberikan kepuasan melalui kualitas produk belum maksimal, sebagaimana data di bawah ini.

\begin{tabular}{|c|c|c|c|c|c|c|}
\hline \multicolumn{7}{|c|}{ Tabel 1.2. Jumlah Komplain Pelanggan } \\
Tahun 2013 - 2017 \\
\hline \multirow{2}{*}{ Tahun } & \multirow{2}{*}{$\begin{array}{c}\text { Jumlah } \\
\text { Pelanggan } \\
\text { Komplain }\end{array}$} & $\begin{array}{c}\text { Jenis Komplain } \\
\text { Kurang }\end{array}$ & $\begin{array}{c}\text { Harga } \\
\text { kurang } \\
\text { bersaing }\end{array}$ & $\begin{array}{c}\text { Kemasan } \\
\text { Kurang } \\
\text { Menarik }\end{array}$ & $\begin{array}{c}\text { Isi } \\
\text { kurang } \\
\text { banyak }\end{array}$ & $\begin{array}{c}\text { Variasi } \\
\text { rasa } \\
\text { sedikit }\end{array}$ \\
\hline 201 & 8433 & & & & 253 & 337 \\
3 & & 843 & 84 & 82 & 0 & 3 \\
\hline 201 & 8560 & & & & 256 & 342 \\
4 & & 856 & 86 & 84 & 8 & 4 \\
\hline 2015 & 8013 & & & & 240 & 320 \\
\hline 201 & 7307 & & & & 219 & 292 \\
6 & & 731 & 73 & 74 & 2 & 3 \\
\hline 2017 & 7184 & & & & 215 & 287 \\
& & 718 & 72 & 74 & 5 & 4 \\
\hline
\end{tabular}




\begin{tabular}{|c|c|c|c|c|c|c|}
\hline \multirow[b]{2}{*}{ Tahun } & \multirow[b]{2}{*}{\begin{tabular}{|l} 
Jumlah \\
Pelanggan \\
Komplain
\end{tabular}} & \multicolumn{5}{|c|}{ Jenis Komplain } \\
\hline & & $\begin{array}{l}\text { Rasa } \\
\text { Kurang }\end{array}$ & $\begin{array}{c}\text { Harga } \\
\text { kurang } \\
\text { bersaing }\end{array}$ & $\begin{array}{l}\text { Kemasan } \\
\text { Kurang } \\
\text { Menarik }\end{array}$ & $\begin{array}{c}\text { Isi } \\
\text { kurang } \\
\text { banyak }\end{array}$ & \begin{tabular}{|c|} 
Varias \\
rasa \\
sedikit
\end{tabular} \\
\hline $\begin{array}{l}\text { Rata } \\
\text {-rata }\end{array}$ & 7899 & 790 & 79 & 79 & $\begin{array}{c}237 \\
0\end{array}$ & $\begin{array}{c}316 \\
0\end{array}$ \\
\hline
\end{tabular}

Berdasarkan data di atas, diketahui jumlah komplain masih cukup tinggi hal ini dapat dilihat bahwa pada tahun 2013 terdapat 8433 pelanggan yang komplain, pada tahun 2014 sebanyak 8560 komplain, pada tahun 2015 sebanyak 8013 komplain, pada tahun 2016 sebanyak 7307 komplain, dan pada tahun 2017 sebanyak 7184 komplain. Adapun jenis komplain yang paling banyak ada pada "Variasi rasa sedikit" sebanyak 3160 komplain. Kondisi ini menjadi tantangan bagi PT Kobe Boga Utama untuk terus meningkatkan potensi yang dimiliki dengan melakukan berbagai perbaikanperbaikan terhadap kelemahan-kelemahan. Penelitian ini bertujuan untuk mengetahui:

1. Kualitas produk pada PT. Kobe Boga Utama.

2. Kepuasan pelanggan pada PT. Kobe Boga Utama.

3. Pengaruh kualitas produk terhadap kepuasan pelanggan pada PT. Kobe Boga Utama.

\section{Manfaat Penelitian}

1. Manfaat teoritis

Penelitian ini diharapkan dapat menjadi rujukan ilmiah bagi penguatan teori dan penelitian berikutnya, sehingga berbagai permasalahan terkait kepuasan pelanggan dapat terselesaikan dengan baik.
2. Manfaat praktis

Penelitian ini diharapkan dapat memberikan masukan kepada perusahaan bagaimana caranya menciptakan kepuasan pelanggan melalui penguatan produk yang berkualitas.

3. Manfaat akademis

Penelitian ini di harapkan dapat bermanfaat bagi akademis dalam bidang manajemen khususnya dalam pengembangan ilmu manajemen pemasaran.

\section{Kerangka Berfikir}

\begin{tabular}{|c|c|}
\hline \multicolumn{2}{|c|}{$\begin{array}{c}\text { Pengaruh Kualitas Produk Terhadap Kepuasan Pelanggan Pada } \\
\text { PT. Kobe Boga Utama Tangerang }\end{array}$} \\
\hline Kualitas Produk (X) & Kepuasan Pelanggan (Y) \\
\hline \begin{tabular}{ll} 
& \multicolumn{1}{c}{ Indikator } \\
1. & Bentulk \\
2. Eitur \\
3. Keberagaman \\
4. Kualitaskinineria \\
5. Kualitas Kesesuaian \\
6. Ketahanan \\
7. Keandalan \\
8. Kemudahan perbaikan \\
9. Gaya
\end{tabular} & $\begin{array}{l}\quad \text { Indikator } \\
\text { 1. Kesesuaian harapan } \\
\text { 2. Minat berkunjung } \\
\text { kembali } \\
\text { 3. Kesediaan } \\
\text { merekomendasikan }\end{array}$ \\
\hline $\begin{array}{l}\text { Sumber: } \\
\text { Kotler (2015:351-352) }\end{array}$ & $\begin{array}{l}\text { Sumber: } \\
\text { Tjiptono (2012:101) }\end{array}$ \\
\hline
\end{tabular}

Gambar 1.2. Kerangka Berpikir

\section{Hipotesis}

1. $\mathrm{H}_{\mathrm{o}}: \mathrm{p}=\mathrm{o}$ Diduga tidak terdapat pengaruh kualitas produk terhadap kepuasan pelanggan pada PT. Kobe Boga Utama.

2. $\mathrm{H}_{\mathrm{a}}: \mathrm{p} \neq \mathrm{O}$ Diduga terdapat pengaruh kualitas produk terhadap kepuasan pelanggan pada PT. Kobe Boga Utama. 


\section{Kajian Literatur}

\section{Kualitas Produk}

Menurut Kotler dan Armstrong (2012:347) menyatakan bahwa "kualitas produk adalah kemampuan suatu produk untuk melakukan fungsi-fungsinya yang meliputi daya tahan, keandalan, ketepatan, kemudahan, operasi dan perbaikan serta atribut lainnya. Bila suatu produk telah dapat menjalankan fungsi-fungsinya dapat dikatakan sebagai produk yang memiliki kualitas baik”. Menurut Kotler dan Keller (2012:143) mendefinisikan "kualitas produk adalah produk atau jasa yang telah memenuhi atau melebihi ekspektasi pelanggan. Berdasarkan definisi menurut para ahli, dapat disimpulkan bahwa kualitas produk adalah suatu bentuk barang atau jasa yang diukur dalam ketingkatan standar mutu keandalan, keistimewaan tambahan, kadar, rasa, serta fungsi kinerja dari produk tersebut yang dapat memenuhi ekspektasi pelanggan".

\section{Kepuasan Pelanggan}

Menurut Kotler dan Keller (2012:78), "kepuasan konsumen adalah perasaan senang atau kekecewaan seseorang setelah membandingkan kinerja atau hasil yang dirasakan dibandingkan dengan harapannya. Kepuasan adalah semacam langkah perbandingan antara pengalaman dengan hasil evaluasi, dapat menghasilkan sesuatu yang nyaman secara rohani, bukan hanya nyaman karena dibayangkan atau diharapkan”. Puas atau tidak puas bukan merupakan emosi melainkan sesuatu hasil evaluasi dari emosi. Tjiptono (2012:146), mengatakan bahwa "kepuasan konsumen merupakan evaluasi purnabeli di mana alternatif yang dipilih sekurang-kurangnya memberikan hasil (outcome) sama atau melampaui harapan konsumen, sedangkan ketidakpuasan timbul apabila hasil yang diperoleh tidak memenuhi harapan pelanggan".

\section{METODE}

\section{Ruang Lingkup Penelitian}

Ruang lingkup penelitian ini adalah penelitian manajemen pemasaran dengan metode kuantitatif dengan eksplanasi deskriptif dan verifikatif. Sugiyono (2012:13) menjelaskan bahwa metode kuantitatif merupakan penelitian berdasarkan pendekatan angka dengan tujuan untuk menguji hipotesis yang telah ditetapkan. Lebih lanjut Sugiyono (2012:147) menjelaskan bahwa "statistik deskriptif adalah statistik yang digunakan untuk menganalisis data dengan cara menjelaskan gambaran data yang telah terkumpul sebagaimana adanya atau aslinya tanpa bermaksud untuk membuat kesimpulan yang berlaku secara umum”. Kemudian Sugiyono (2012:207) menambahkan bahwa penelitian inferensial atau verifikatif adalah teknik statistik yang digunakan untuk menjawab hipotesis yang diajukan.

\section{Populasi}

Populasi dalam penelitian ini adalah konsumen yang melakukan pembelian di PT. Kobe Boga Utama dengan rata-rata 
jumlah pelanggan selama semester II (Desember 2018) sebanyak 3179.

\begin{tabular}{|c|c|c|c|}
\hline \multicolumn{4}{|c|}{ Tabel 1.3. Populasi Penelitian } \\
\hline No & Bulan & $\begin{array}{c}\text { Jumlah } \\
\text { Pelanggan }\end{array}$ & Keterangan \\
\hline 1 & Juli & 381 & - \\
\hline 2 & Agustus & 413 & - \\
\hline 3 & September & 477 & - \\
\hline 4 & Oktober & 477 & - \\
\hline 5 & November & 636 & - \\
\hline 6 & Desember & 795 & - \\
\hline \multicolumn{2}{|c|}{ Jumlah } & 3179 & \\
\hline
\end{tabular}

\section{Sampel}

Dalam penelitian ini, teknik penentuan jumlah sampel menggunakan rumus dari Slovin dalam Umar Husein (2012:108) yaitu sebagai berikut: $n=\frac{\mathrm{N}}{1+\mathrm{N}(e)^{2}}$

Dimana:

$$
\begin{array}{ll}
\mathrm{n} & =\text { Jumlah sampel } \\
\mathrm{N} & =\text { Jumlah populasi } \\
\mathrm{e}^{2} & \text { = Presisi yang ditetapkan / eror }
\end{array}
$$

Sehingga $\mathrm{n}=\frac{3179}{1+3179(10 \%)^{2}}=96,92$ dibulatkan menjadi 97 sampel.

\section{HASIL dan PEMBAHASAN}

\section{Gambaran Umum Objek Penelitian}

Didirikan pada tahun 1979 oleh Hestia Utomo \& Sarwo Utomo, KOBE memulai perjalanannya sebagai industri rumahan di Semarang. Produk pertama KOBE adalah Tepung Bumbu yang kemudian menjadi tepung bumbu pertama di Indonesia. Sesudah mengawali eksistensinya sebagai pelopor, berbagai inovasi terus mewarnai setiap tahapan dalam sejarah pertumbuhan perusahaan. Dengan berfokus pada hasil kualitas produk yang terbaik untuk konsumen ritel Indonesia, KOBE berhasil berkembang dengan cepat dan pasti. Pada

tahun 1995, pabrik KOBE dipindahkan ke kawasan industri di Tangerang untuk pengembangan bisnis. Pada tahun yang sama diluncurkan merek khusus ekspor bernama Bali Kitchen, yang merupakan serangkaian produk lengkap dengan konsep kuliner tradisional Indonesia. Produk Bali Kitchen meliputi aneka rempah, bumbu, saus, mie, acar dan makanan pelengkap khas Indonesia lainnya. Pada tahun 2006, KOBE meluncurkan divisi Food Service untuk melayani para pelanggan industri yang bergerak dalam bidang makanan dan retail. Melalu divisi Food Service ini, KOBE menawarkan solusi produk maupun kebutuhan layanan yang disesuaikan dengan kebutuhan para pelanggan. Pelanggan industri KOBE saat ini meliputi beberapa pemain multinasional dalam industri makanan dan ritel. Berbagai inovasi produk yang dilakukan untuk memenuhi kebutuhan konsumen Indonesia terus meningkatkan eksistensi merek KOBE dalam kancah ritel Indonesia. Dengan konsep yang kuat dan kualitas produk yang terbaik, produk KOBE telah menjadi pemimpin pasar diberbagai kategori. Keberhasilan inovasi KOBE lainnya meliputi sambal tabur BonCabe, BonChili

\begin{tabular}{|c|c|c|c|}
\hline \multicolumn{4}{|c|}{$\begin{array}{c}\text { Tabel 1.4. Karakteristik Responden } \\
\text { Berdasarkan Jenis Kelamin }\end{array}$} \\
\hline No & Keterangan & Jumlah & Persentase \\
\hline 1 & Laki-laki & 56 & $57 \%$ \\
\hline 2 & Perempuan & 41 & $43 \%$ \\
\hline \multicolumn{2}{|r|}{ Total } & 97 & $100 \%$ \\
\hline
\end{tabular}
dan Selera Saus Tiram.

\section{Karakteristik Responden}


Berdasarkan tabel di atas terlihat bahwa sebagian besar responden adalah laki-laki sebanyak 56 orang atau $57 \%$ dan responden perempuan sebanyak 41 orang atau $43 \%$. Hal ini menunjukkan bahwa responden yang mengisi kuesioner telah sesuai dengan jumlah sampel yang ditetapkan, yaitu sebanyak 97 orang.

Tabel 1.5. Karakteristik Responden Berdasarkan Usia

\begin{tabular}{|c|c|c|c|}
\hline No & Keterangan & Jumlah & Persentase \\
\hline 1 & $\leq 25$ tahun & 19 & $20 \%$ \\
2 & $26-35$ tahun & 32 & $32 \%$ \\
3 & $36-45$ tahun & 34 & $35 \%$ \\
4 & $\geq 46$ tahun & 12 & $13 \%$ \\
\hline \multicolumn{2}{|c|}{ Total } & $\mathbf{9 7}$ & $\mathbf{1 0 0} \%$ \\
\hline
\end{tabular}

Sumber: Data Primer Diolah (2019)

Berdasarkan tabel di atas terlihat bahwa responden didominasi oleh responden berusia di antara 36-45 tahun yaitu sebanyak 34 orang atau $35 \%$, selanjutnya responden berusia antara 26-35 tahun sebanyak 32 orang atau 32\%, responden berusia $\leq 25$ tahun sebanyak 19 orang atau 20\%, dan responden usia sama dengan di atas 46 tahun sebanyak 12 orang. Hal ini menunjukkan bahwa konsumen PT. Kobe Boga Utama berasal dari berbagai kalangan, baik usia muda maupun usia dewasa.

\begin{tabular}{|c|c|c|c|}
\hline & $\begin{array}{l}\text { Tabel 1.6. Dat } \\
\text { Ber }\end{array}$ & $\begin{array}{l}\operatorname{arakteri} \\
\text { sarkan } \mathrm{S}\end{array}$ & $\begin{array}{l}\text { Responden } \\
\text { us }\end{array}$ \\
\hline No & Keterangan & Jumlah & Persentase \\
\hline $\begin{array}{l}1 \\
2 \\
3 \\
4\end{array}$ & $\begin{array}{l}\text { Karyawan } \\
\text { Wirausaha } \\
\text { Pegawai } \\
\text { Negeri Sipil } \\
\text { Rumah } \\
\text { Tangga }\end{array}$ & $\begin{array}{l}23 \\
30 \\
29 \\
14\end{array}$ & $\begin{array}{l}24 \% \\
31 \% \\
30 \% \\
15 \%\end{array}$ \\
\hline \multicolumn{2}{|c|}{ Total } & 97 & 100\% \\
\hline
\end{tabular}

Berdasarkan tabel di atas, di ketahui bahwa konsumen PT. Kobe Boga Utama dari kalangan karyawan sebanyak 23 orang, dari kalangan wirausaha sebanyak 30 orang, dari kalangan pegawai negeri sipil sebanyak 29 orang dan ibu rumah tangga sebanyak 14 orang. Data ini memberikan informasi bahwa konsumen PT. Kobe Boga Utama terdiri dari berbagai kalangan status sosial, mulai dari karyawan hingga ibu rumah tangga.

\section{Uji Validitas}

\begin{tabular}{|c|c|c|c|c|}
\hline \multicolumn{5}{|c|}{$\begin{array}{l}\text { Tabel 1.7. Uji Validitas } \\
\text { Variabel Kualitas produk (X) }\end{array}$} \\
\hline No & Kuesioner & $\mathbf{r}_{\text {hitung }}$ & $\mathbf{r}_{\text {tabel }}$ & $\begin{array}{l}\text { Kesim } \\
\text { pulan }\end{array}$ \\
\hline 1 & Pernyataan 1 & 0,506 & 0,198 & Valid \\
\hline 2 & Pernyataan 2 & 0,636 & 0,198 & Valid \\
\hline 3 & Pernyataan 3 & 0,522 & 0,198 & Valid \\
\hline 4 & Pernyataan 4 & 0,685 & 0,198 & Valid \\
\hline 5 & Pernyataan 5 & 0,646 & 0,198 & Valid \\
\hline 6 & Pernyataan 6 & 0,543 & 0,198 & Valid \\
\hline 7 & Pernyataan 7 & 0,674 & 0,198 & Valid \\
\hline 8 & Pernyataan 8 & 0,458 & 0,198 & Valid \\
\hline 9 & Pernyataan 9 & 0,600 & 0,198 & Valid \\
\hline 10 & Pernyataan 10 & 0,632 & 0,198 & Valid \\
\hline
\end{tabular}

Berdasarkan tabel di atas, diketahui bahwa semua pernyataan (kuesioner) variabel kualitas produk memiliki nilai $\boldsymbol{R}$ Products Moment ( $\mathbf{r}_{\text {hitung) }}$ lebih besar dari $\mathbf{r}_{\text {tabel, }}$ maka dapat disimpulkan kuesioner variabel kualitas produk yang diajukan dalam penelitian ini adalah valid.

Tabel 1.8. Uji Validitas
\begin{tabular}{|c|c|c|c|c|}
\hline Variabel Kepuasan konsumen (Y) \\
\hline No & Indikator & $\mathbf{r}_{\text {hitung }}$ & $\mathbf{r}_{\text {tabel }}$ & Kesimpulan \\
\hline 1 & Pernyataan 1 & 0,595 & 0,198 & Valid \\
\hline 2 & Pernyataan 2 & 0,636 & 0,198 & Valid \\
\hline 3 & Pernyataan 3 & 0,525 & 0,198 & Valid \\
\hline 4 & Pernyataan 4 & 0,673 & 0,198 & Valid \\
\hline 5 & Pernyataan 5 & 0,660 & 0,198 & Valid \\
\hline 6 & Pernyataan 6 & 0,661 & 0,198 & Valid \\
\hline 7 & Pernyataan 7 & 0,683 & 0,198 & Valid \\
\hline
\end{tabular}




\begin{tabular}{|c|c|c|c|c|}
\hline No & Indikator & $\mathbf{r}_{\text {hitung }}$ & $\mathbf{r}_{\text {tabel }}$ & Kesimpulan \\
\hline 8 & Pernyataan 8 & 0,597 & 0,198 & Valid \\
\hline 9 & Pernyataan 9 & 0,510 & 0,198 & Valid \\
\hline 10 & Pernyataan 10 & 0,680 & 0,198 & Valid \\
\hline
\end{tabular}

Sumber: Data diolah (2019)

Berdasarkan tabel di atas, diketahui bahwa semua pernyataan (kuesioner) variabel kepuasan konsumen memiliki nilai $\boldsymbol{R}$ Products Moment ( $\mathbf{r}_{\text {hitung) }}$ lebih besar dari $\mathbf{r}_{\text {tabel}}$, maka dapat disimpulkan kuesioner variabel kepuasan konsumen yang diajukan dalam penelitian ini adalah valid.

\section{Uji Reliabilitas}

\begin{tabular}{|c|c|c|c|c|}
\hline \multicolumn{5}{|c|}{ Tabel 1.9. Uji Reliabilitas } \\
No & Variabel & $\begin{array}{c}\text { Nilai } \\
\text { Cronbach } \\
\text { Alpha }\end{array}$ & $\begin{array}{c}\text { Kriteria } \\
\text { Minimum }\end{array}$ & $\begin{array}{c}\text { Kesim } \\
\text { pulan }\end{array}$ \\
\hline 1 & $\begin{array}{l}\text { Kualitas } \\
\text { produk }\end{array}$ & 0,794 & 0,60 & Reliabel \\
\hline 2 & $\begin{array}{l}\text { Kepuasan } \\
\text { konsumen }\end{array}$ & 0,824 & 0,60 & Reliabel \\
\hline
\end{tabular}

Berdasarkan tabel tersebut di atas, diketahui bahwa semua variabel (kualitas produk dan kepuasan konsumen) memiliki nilai cronbach alpha lebih besar (>) dari o,6o maka dapat disimpulkan kuesioner variabel dalam penelitian ini adalah reliabel. Hasil ini membuktikan bahwa instrumen (kuesioner) yang dibuat telah sesuai dengan variabel yang diteliti, data yang valid dan konsisten kebenaran. Sehingga data dapat dilanjutkan pada analisis berikutnya (analisis Regresi).

\section{Uji Normalitas}

\begin{tabular}{|ll|r|}
\hline \multicolumn{2}{|c|}{ Tabel 1.10. Uji Normalitas } \\
\hline $\mathrm{N}$ & & \multicolumn{2}{|c|}{ Unstandardized Residual } \\
Normal & Mean & 97 \\
Parametersa,b & Std. Deviation & .000000 \\
Most Extreme & Absolute & 5.03306490 \\
Differences & Positive & .097 \\
& Negative & .046 \\
Kolmogorov-Smirnov Z & -.097 \\
Asymp. Sig. (2-tailed) & .955 \\
\hline Sumber: Data diolah (2019) & .322 \\
\hline
\end{tabular}

Berdasarkan tabel di atas, diketahui bahwa nilai residual variabel kualitas produk dan kepuasan konsumen memiliki nilai Asymp Sig sebesar 0.322 lebih besar dari kriteria minimum 0.05, maka dapat disimpulkan bahwa secara multivariat data dalam penelitian ini berdistribusi normal.

\section{Uji Koefisien Korelasi}

\begin{tabular}{|l|l|r|r|}
\hline \multicolumn{3}{|c|}{ Tabel 11. Uji Koefisien Korelasi } \\
\hline \multirow{2}{*}{$\begin{array}{l}\text { Kualitas } \\
\text { produk }\end{array}$} & $\begin{array}{l}\text { Kualitas } \\
\text { produk } \\
\text { Correlation }\end{array}$ & $\begin{array}{c}\text { Kepuasan } \\
\text { konsumen }\end{array}$ \\
\cline { 2 - 4 } & Sig. (2-tailed) & 1 & $.204^{*}$ \\
\cline { 2 - 4 } & N & & .045 \\
\hline \multirow{2}{*}{$\begin{array}{l}\text { Kepuasan } \\
\text { konsumen }\end{array}$} & $\begin{array}{l}\text { Pearson } \\
\text { Correlation }\end{array}$ & $.204^{*}$ & \\
\cline { 2 - 4 } & Sig. (2-tailed) & .045 & \\
\cline { 2 - 4 } & N & 97 & \\
\hline
\end{tabular}

**. Correlation is significant at the o.o1 level (2-tailed). Sumber: Data diolah (2019)

Berdasarkan tabel di atas, dapat dikemukakan bahwa nilai korelasi variabel kualitas produk dengan kepuasan konsumen sebesar 0.204 masuk pada kategori "Rendah". Dengan kata lain, terdapat hubungan yang rendah antara variabel kualitas produk dengan kepuasan konsumen. 


\section{Uji Regresi Linear Sederhana}

Tabel 1.12. Analisis Regresi Linear

Coefficients ${ }^{\mathrm{a}}$

\begin{tabular}{|l|l|r|r|r|r|r|}
\hline \multicolumn{2}{|l|}{} & \multicolumn{2}{|c|}{$\begin{array}{c}\text { Unstandardized } \\
\text { Coefficients }\end{array}$} & $\begin{array}{c}\text { Standardized } \\
\text { Coefficients }\end{array}$ & $\mathrm{t}$ & Sig. \\
\hline \multirow{2}{*}{ Model } & \multicolumn{1}{c|}{$\mathrm{B}$} & $\begin{array}{c}\text { Std. } \\
\text { Error }\end{array}$ & \multicolumn{1}{c|}{ Beta } & & \\
\hline \multirow{2}{*}{1} & (Constant) & 31.808 & 4.493 & & 7.080 & .000 \\
\cline { 2 - 6 } & $\begin{array}{l}\text { Kualitas } \\
\text { produk }\end{array}$ & .224 & .110 & .204 & 2.034 & .045 \\
\hline
\end{tabular}

a. Dependent Variable: Kepuasan konsumen Sumber: Data diolah (2019)

Dari tabel di atas, dapat dikemukakan sebagai berikut:

Persamaan Regresi $\quad \mathrm{Y}=31.808+0.224 \mathrm{X}$

$\mathrm{t}_{\text {hitung }}=2.034$

Nilai Signifikan $\quad=0.045$

Berdasarkan keterangan tersebut di atas, maka dapat dikemukakan penjelasan sebagai berikut:

1. Nilai konstanta sebesar 31.808 memiliki arti, meskipun tidak ada pengaruh dari variabel kualitas produk, konsumen PT. Kobe Boga Utama tetap memiliki kepuasan sebesar 31.808.

2. Variabel kualitas produk terbukti berpengaruh positif signifikan terhadap kepuasan konsumen dalam hal ini dapat ditunjukkan oleh nilai koefisien regresi sebesar 0.224, nilai $t_{\text {hitung }}$ sebesar 2.034 lebih besar dari 1.985 dan nilai signifikansi sebesar o,045 lebih kecil dari 0,05. Temuan ini mengonfirmasi teori dan penelitian terdahulu, bahwa kualitas produk secara logis dapat meningkatkan kepuasan konsumen.

\section{Uji Koefisien Determinasi}

Tabel 1.13. Uji Koefisien Determinasi Model Summary ${ }^{b}$

\begin{tabular}{|c|c|c|c|c|}
\hline Model & $\mathrm{R}$ & R Square & $\begin{array}{c}\text { Adjusted R } \\
\text { Square }\end{array}$ & $\begin{array}{c}\text { Std. Error } \\
\text { of the } \\
\text { Estimate }\end{array}$ \\
\hline 1 & $.204^{a}$ & .142 & .132 & 5.059 \\
\hline
\end{tabular}

a. Predictors: (Constant), Kualitas produk

b. Dependent Variable: Kepuasan konsumen Sumber: Data diolah (2019)

Berdasarkan tabel di atas, di ketahui bahwa nilai kontribusi ( $R$ Square) variabel kualitas produk terhadap kepuasan konsumen sebesar 0,142. Artinya kualitas produk memiliki kemampuan menjelaskan variabel kepuasan konsumen sebesar 14,2\% sedangkan sisanya sebesar 85,8\% dijelaskan oleh variabel lain di luar penelitian ini. Temuan ini menegaskan, bahwa produk yang terjamin mutunya secara eksplisit dapat meningkatkan kepuasan konsumen, bahkan dapat juga meningkatkan kesetiaan (loyalitas pembelian).

\section{Uji Signifikansi (Uji t)}

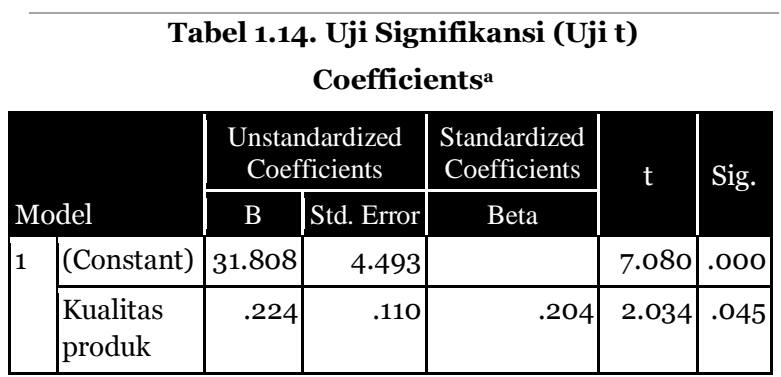

a. Dependent Variable: Kepuasan konsumen

Sumber: Data diolah (2019)

Berdasarkan tabel di atas, maka dapat dikemukakan penjelasan sebagai berikut:

1. Variabel Kualitas produk memiliki nilai $t_{\text {hitung }}$ lebih besar dari $t_{\text {tabel }}(2.034>$ 1.985). Artinya kualitas produk terbukti berpengaruh positif terhadap kepuasan konsumen. Dengan tafsiran, jika 
kualitas produk meningkat sebesar 1 satuan maka kepuasan konsumen akan meningkat sebesar 0.224.

2. Variabel kualitas produk memiliki nilai signifikan lebih kecil dari 0,05 (0.045 < 0,05). Artinya kualitas produk berpengaruh signifikan terhadap kepuasan konsumen. Dengan tafsiran, variabel kualitas produk mampu mempengaruhi kepuasan konsumen dengan baik dengan koefisien regresi sebesar 0.224 .

Berdasarkan analisis di atas maka dapat disimpulkan $\mathrm{H}_{\mathrm{a}}$ diterima dan $\mathrm{H}_{\mathrm{o}}$ ditolak. Sehingga disimpulkan kualitas produk berpengaruh signifikan terhadap kepuasan pelanggan pada PT. Kobe Boga Utama.

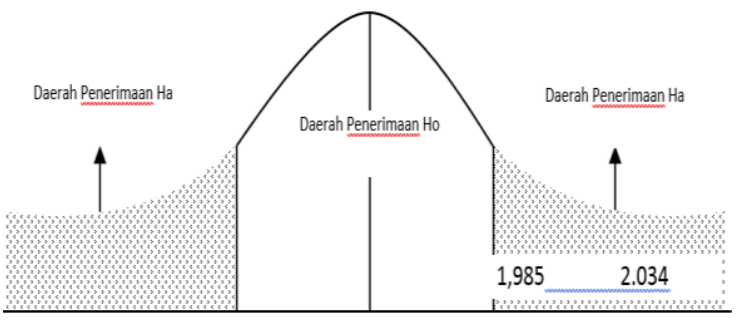

Gambar 1.3. Kurva Daerah Penerimaan dan Penolakan Hipotesis

\section{SIMPULAN}

\section{Kesimpulan}

Berdasarkan hasil analisis dan pembahasan maka dapat diambil kesimpulan sebagai berikut :

1. Hasil deskripsi kuesioner menunjukkan kualitas produk PT. Kobe Boga Utama dipersepsikan baik, hal ini dapat dilihat pada nilai rata-rata jawaban responden sebesar 4.06 masuk pada kategori $(3,40-4,19)$.
2. Hasil deskripsi kuesioner menunjukkan kepuasan konsumen PT. Kobe Boga Utama dipersepsikan baik, hal ini dapat dilihat pada nilai rata-rata jawaban responden sebesar 4.05 masuk pada kategori $(3,40-4,19)$.

3. Hasil analisis signifikansi menunjukkan bawah kualitas produk berpengaruh positif dan signifikan terhadap kepuasan konsumen dengan hasil $t_{\text {hitung }}>t_{\text {tabel }}$ sebesar $(2.034>$ 1.985) dan persamaan $\mathrm{Y}=31.808+$ $0.224 \mathrm{X}$, artinya $\mathrm{H}_{\mathrm{o}}$ ditolak dan $\mathrm{Ha}$ diterima. Dengan tafsiran, jika kualitas produk meningkat sebesar 1 satuan maka kepuasan konsumen akan meningkat sebesar 0.224 .

\section{Saran}

Berdasarkan hasil analisis dan kesimpulan penelitian di atas, maka dapat dikemukakan beberapa saran sebagai berikut:

1. Hasil analisis deskriptif kuesioner menunjukkan indikator yang paling lemah dari kualitas produk adalah gaya produk (dalam hal ini kemasan). Oleh karenanya, diharapkan kepada PT. Kobe Boga Utama untuk membuat variasi kemasan yang menarik (kombinasi antara warna, desain dan bentuk kemasan).

2. Hasil analisis deskriptif kuesioner menunjukkan indikator yang paling lemah dari variabel kepuasan konsumen adalah kesediaan merekomendasikan. Oleh karenanya, diharapkan kepada PT. Kobe Boga 
Utama untuk membangun hubungan dengan konsumen, misalnya dengan membuat komunitas masak Kobe atau perlombaan masak atau sejenisnya.

3. Hasil analisis regresi linear sederhana menunjukkan pengaruh kualitas produk terhadap kepuasan konsumen sebesar 14,2\% sedangkan sisanya sebesar $85,8 \%$ dijelaskan oleh variabel lain di luar penelitian ini. Diharapkan kepada peneliti berikutnya untuk menggunakan variabel lain, seperti promosi, kualitas pelayanan, kemitraan, kepercayaan konsumen dan lain sebagainya sehingga kepuasan konsumen menjadi lebih baik.

4. Diharapkan kepada peneliti berikutnya untuk menggunakan metode, objek dan unit analisis yang berbeda sehingga hasil penelitian menjadi lebih komprehensif.

\section{DAFTAR PUSTAKA}

Barnes, James G. 2013. "Secrets of Customer Relationship

Management”. Yogyakarta: Andi.

Dewi Janita, 2012, "Pemasaran Pariwisata

Yang Bertanggung Jawab”, Pinus Book, Publisher Jakarta.

Dharmesta dan Irawan. 2015. "Manajemen

Pemasaran Modern”. Edisi Kedua. Liberty. Yogyakarta.

Ghozali, Imam. 2016. "Aplikasi Analisis Multivariate Dengan Program IBM SPSS 23”. Badan Penerbit Universitas Diponegoro. Semarang.
Handoko, T. H. 2014. "Manajemen Personalia dan Sumber Daya Manusia (edisi 2)”. BPFE. Yogyakarta.

Hasibuan, H. Malayu S. P. 2014. "Manajemen Dasar. Pengertian dan Masalah”. Bumi Aksara. Jakarta.

Hurriyati, Ratih. 2010. "Bauran Pemasaran dan Loyalitas Konsumen”. Alfabetha. Bandung.

Irawan, Juwandi Hendy. 2014. "Kepuasan Pelayanan Jasa”. Jakarta : Erlangga. Istijanto, 2011. "Aplikasi Praktis Riset Pemasaran”. Jilid II. Edisi Kesebelas. Alih Bahasa Benyamin Molan. Jakarta : Indeks. and Gary Armstrong. 2012. "Prinsipprinsip Pemasaran”. Jilid 1. Erlangga. Jakarta.

and K.L. Keller. 2012. "Manajemen Pemasaran”. Edisi Ke 14. Jilid Ke 1. Erlangga. Jakarta.

Kurniawan. 2011. "Management Marketing”. Journal of A Case Study in Air Asia, Hal. 21.

Rangkuti, Fredly, 2015, "Messuring Customer Satisfaction”, PT, Gramedia Pustaka Utama, Jakarta.

Riduwan dan Engkos Achmad Kuncoro. 2013. "Cara Menggunakan dan. Memaknai Analisis Jalur (Path Analysis)”. Cetakan Ketiga. Alfabeta. Bandung.

Sugiyono. 2012. "Metode Penelitian Bisnis”. Alfabeta. Bandung. 
Swastha, Basu. 2012. "Manajemen

Penjualan: Pelaksanaan Penjualan”, BPFE. Yogyakarta.

Tjiptono, Fandy. 2012. "Strategi Pemasaran”. Yogyakarta: Andi.

Umar, Husein. 2012. "Metode Penelitian

Untuk Skripsi dan Tesis Bisnis".

Rajagrafindo. Jakarta. 